\title{
PENGEMBANGAN DESAIN RUMAH KUTAI UNTUK DAERAH RAWA
}

\section{(Kutai House Design Development for the Swampy Area)}

\author{
Anna Rulia*, Anton Esfianto**, Alfin Y.N***, M.Fikri.A****, Sopian.N***** \\ *,***,****,*****Arsitektur Politeknik Negeri Samarinda \\ Jalan Ciptomangunkusumo Samarinda \\ Email: anna30rulia@gmail.com \\ ** Teknik Sipil Politeknik Negeri Samarinda \\ Jalan Ciptomangunkusumo Samarinda
}

Diterima: 29 Januari 2019; Direvisi: 4 Juli 2019; Disetujui: 5 Juli 2019

\begin{abstract}
ABSTRAK
Penelitian ini bertujuan untuk mengembangkan desain rumah Kutai sebagai solusi alternatif dalam pembangunan perumahan pada daerah rawa. Desain yang berkembang saat ini umumnya merupakan model rumah-rumah beton yang berpotensi membuat banjir akibat tertutupnya jalur air sebagai konsekuensi penimbunan lahan. Rumah Kutai memiliki karakter sederhana namun mengandung estetika yang memberi jati diri kelokalan. Pengembangan model konstruksi juga dapat dilakukan seiring perkembangan teknologi. Penelitian ini menggunakan pendekatan metode perancangan arsitektur lima langkah meliputi perhitungan kebutuhan ruang, menentukan modul bangunan, mengembangkan pilihan desain, menetapkan desain terpilih serta membuat gambar arsitekturalnya. Lokasi perancangan adalah di Kalimantan Timur. Target capaian adalah dihasilkannya pengembangan desain rumah Kutai yang dapat menjadi alternatif solusi perumahan di daerah rawa yang tetap memperhatikan unsur estetika sekaligus sebagai usaha pelestarian kekayaan arsitektur Indonesia.
\end{abstract}

Kata kunci: Rumah, Kutai, desain, daerah rawa, arsitektur

\begin{abstract}
This research aims to develop the Kutai house design as an alternative solution for housing on the swampy area. The current design is generally a model of concrete houses that have the potential to cause flooding due to the closure of waterways as a consequence of landfilling. Despite its simplicity, Kutai house design has aesthethic value and strong local characteristic. Design can also be developed in the building technology. This reseach used the five steps of architectural design method that includes calculating space requirements, determining building modules, developing design choices, setting selected designs and making architectural drawings. Located in Kalimantan Timur, the output of this research is not only can be seen as an alternative housing design solution in swamp areas but also can be considered as an effort to preserve the wealth of Indonesian architecture.
\end{abstract}

Keywords: House, Kutai, design, swampy area, architecture

\section{PENDAHULUAN}

Sebagai Negara maritim, Indonesia memiliki daerah rawa seluas 33,40 sampai 39,40 juta Ha tersebar di pulau Sumatera, Sulawesi, kalimantan dan Papua. Di Kalimantan Timur sendiri luas rawa sekitar 575.437 Ha dengan struktur geologi dan bentuk lahan (land form) tersusun atas endapan sedimen liat berupa dataran banjir sungai. Selain digunakan untuk pertanian, area rawa juga banyak yang digunakan sebagai daerah pemukiman. Dari data Kementerian 
Pekerjaan Umum dan Perumahan Rakyat pada tahun 2015 terdapat backlog (angka kekurangan perumahan) hingga 11,4 juta unit rumah. Dalam hal ini, yang paling banyak mengalami hambatan dalam pemenuhan perumahan adalah masyarakat berpenghasilan rendah. Untuk Kalimantan Timur sendiri, dari data Real Estate Indonesia didapatkan kekurangan rumah sekitar 140 ribu unit per tahunnya, sementara yang mampu dibuat oleh REI hanya sekitar 10 ribu unit per tahun.

Pemenuhan perumahan sulit tercapai jika pembangunan perumahan hanya mengacu pada konstruksi permanen mengingat biaya yang diperlukan untuk membangun bangunan permanen tidaklah sedikit. Selain itu, model perumahan yang ditawarkan oleh developer umumnya adalah konstruksi permanen yang menutup/menimbun tanah. Dari penelitian yang dilakukan oleh Hidayati dan Octavia (2013) konstruksi seperti ini tidak dianjurkan untuk daerah rawa karena menutup jalur air. Jika daerah-daerah rawa yang digunakan untuk pemukiman ditimbun oleh konstruksi permanen, maka akan terjadi banjir. Hal ini dapat dilihat pada sebaran banjir yang meluas pada kota-kota di Kalimantan Timur.

Salah satu alternatif yang dapat dipertimbangkan untuk penyelesain perumahan untuk daerah rawa ini adalah menggunakan desain rumah panggung seperti yang ada pada rumah Kutai. Rumah Kutai menggunakan model berpanggung sehingga memungkinkan air untuk mengalir. Hal ini diperkuat oleh temuan Beddu (2015) bahwa dipandang dari sisi keberlanjutan, rumah berpanggung dipandang lebih sesuai karena menjaga kelestarian sumber daya air. Konstruksi berpanggung memang direkomendasikan untuk area-area berair seperti bantaran sungai (Wononimbar, 2014). Dengan model yang tidak menempel pada tanah, sistem ini juga ternyata efektif mengurangi jumlah penghuni yang menderita ISPA (Ernawati dan Laksmitasari, 2013).

Selanjutnya, gaya arsitektur Kutai sendiri dipilih dalam usulan penelitian ini karena bentuknya yang sederhana namun memiliki karakter estetika yang khas. Berbeda dengan rumah Lamin suku Dayak, rumah Kutai memang kurang dikenal dalam ranah arsitektur tradisional Indonesia. Rumah-rumah Kutai yang di masa lalu menghiasi jalan-jalan utama di Kalimantan Timur, saat ini sebagian besar sudah musnah berganti deretan ruko dan kantor. Jika hal ini terus dibiarkan maka citra kota yang terbentuk akhirnya tidak mewujudkan jati diri kelokalan (Apprimavista et al, 2014). Salah satu wujud kebudayaan dalam bentuk fisik adalah aspek rumah tinggal sebagai wadah perwujudan tradisi yang dapat dilihat selain dari perilaku penghuninya (Darma et al, 2017). Berbeda dengan rumah tradisional Jawa, rumah Kutai dibuat menetap pada lokusnya sehingga ketika terjadi perubahan fungsi dan kepentingan, rumah-rumah ini cenderung dihancurkan karena tidak dapat dipindah. Oleh karena itu, penelitian ini bertujuan untuk merancang pengembangan rumah Kutai yang sesuai dengan karakter daerah rawa dan membantu mewujudkan ciri khas kelokalan pada kota-kota di Kalimantan Timur.

\section{METODE}

Perancangan ini mengambil beberapa langkah yang diperlukan sebagaimana merancang rumah yakni (1) menghitung kebutuhan ruang; (2) menentukan modul; (3) mengembangkan pilihan desain; (4) menetapkan desain terpilih dan (4) mendesain bangunan dan komponennya. Adapun penggambaran desain terpilih menggunakan program gambar berbantu komputer yakni AutoCAD dan Sketch Up. Metode penggambaran ini dirangkai dengan penjelasan deskriptif mengenai hasil yang didapatkan.

\section{HASIL DAN PEMBAHASAN}

Rumah Kutai adalah rumah khas dari suku Kutai di provinsi Kalimantan Timur. Suku ini banyak bermukim pada area bantaran Sungai Mahakam seperti kota Tenggarong, Muara Kaman dan Kotabangun. Masyarakat Kutai sangat akrab dengan air, demikian pula bentukan 
rumahnya. Menurut buku Puncak Kebudayaan Lama dan Asli Kalimantan Timur (1996) rumah Kutai memiliki empat tipe yakni :

a. Rumah Gudang

Rumah gudang merupakan rumah dimana bagian depannya berbentuk segitiga (pelana) yang berdindingkan papan, demikian pula pada bagian belakangnya. Umumnya pada bagian depan ditambahkan teras tanpa dinding, dengan berkandang rasi atau pagar dan atap yang condong ke depan.

b. Koyok meraong

Merupakan bentuk rumah yang umum sebelum Perang Dunia II dimana bagian atap bagian belakang saling bertumbang lebih tinggi dari pada bagian depannya.

c. Gajah Menyusu

Merupakan bentuk rumah dimana atap bagian belakang bangunan lebih rendah daripada bagian depannya sehingga nampak seakan-akan anak gajah menyusu pada induknya.

d. Rumah Palimasan

Merupakan rumah dengan bagian atap berbentuk limas (trapezium). Ada yang memiliki teras (kandang rasi) atau pun tidak. Bentuk ini merupakan bentuk yang paling banyak dipakai untuk kaum bangsawan/istana.

Orientasi utama rumah Kutai adalah sungai/halaman/jalan, karena itu pencapaian ke bangunan menggunakan system frontal atau langsung. Untuk lay out ruang, rumah Kutai umumnya pada bagian depan memiliki ruang tamu, kamar tidur, lorong yang diperbesar sebagai ruang keluarga dan juga sebagai perpanjangan ruang tamu ketika diadakan acara. Pada bagian belakang terdapat dapur, gudang, kamar mandi yang sekaligus berfungsi sebagai toilet. Untuk bagian belakang area cuci dan jemur berupa pelataran dimana ruang-ruang service berada. Seni ukir atau ragam hias Kutai dipengaruhi oleh arsitektur Melayu dan Jawa. Motif yang dipakai umumnya adalah bunga mawar, melati, padma dan daun yang merambat/sulur. Adapula yang menggunakan permainan geometris sederhana. Ukiran berbentuk orang dan binatang jarang dipakai kecuali berkaitan dengan benda-benda tradisi upacara, perabotan rumah tangga dan bagian istana. Dalam desain ini yang dikembangkan adalah rumah Kutai model Gudang. Model rumah Gudang dipilih karena secara bentukan atap lebih sederhana hanya berupa atap pelana yang menerus ke belakang. Hal ini akan memudahkan dari sisi perancangan bangunan. Selain itu akan menghemat pekerjaan dan biaya yang lebih murah dibandingkan model-model lainnya.

Kebutuhan ruang yang utama dalam sebuah rumah adalah ruang tidur, kamar mandi/WC serta dapur. Selain ruang-ruang dasar tersebut, fungsi hunian juga dapat dilengkapi dengan ruang keluarga. Pada bagian depan bangunan rumah Kutai umumnya terdapat teras. Keberadaan ruang-ruang ini sangat diperlukan bukan hanya sebagai wadah kegiatan namun juga sangat vital secara sosial. Standar ruang yang digunakan mengacu pada ukuran yang ada dalam Data Arsitek (Neufert, 2003). Berikut adalah standar kebutuhan ruang yang menjadi acuan dalam desain.

Rumah gudang merupakan rumah dimana bagian depannya berbentuk segitiga (pelana) yang berdindingkan papan, demikian pula pada bagian belakangnya. Umumnya pada bagian depan ditambahkan teras tanpa dinding, dengan berkandang rasi atau pagar dan atap yang condong ke depan. Model ini merupakan model terbanyak yang masih dapat ditemui baik di kota Samarinda maupun pada wilayah-wilayah Kabupaten Kutai Kartanegara. Ada beberapa variasi dari model rumah gudang ini. Yang paling sederhana adalah model yang tidak memiliki tambahan ruang atau lantai teras. Untuk mencegah tempias pada bagian depan ditambahkan teritisan. Pada daerah-daerah di mana merupakan daerah padat penduduk seperti Samarinda sebagian wajah rumah ini sudah mengalami perubahan. Hal ini terjadi berkaitan dengan fungsi tambahan seperti bangunan komersial. Hal tersebut dapat dilihat pada gambar 
di bawah ini. Model rumah gudang ini sudah dilengkapi dengan area teras depan dengan kombinasi lengkungan (arch) pada bagian atas teras. Sebagai pelengkap juga ditambahkan pagar atau kandang rasi dalam istilah setempat.

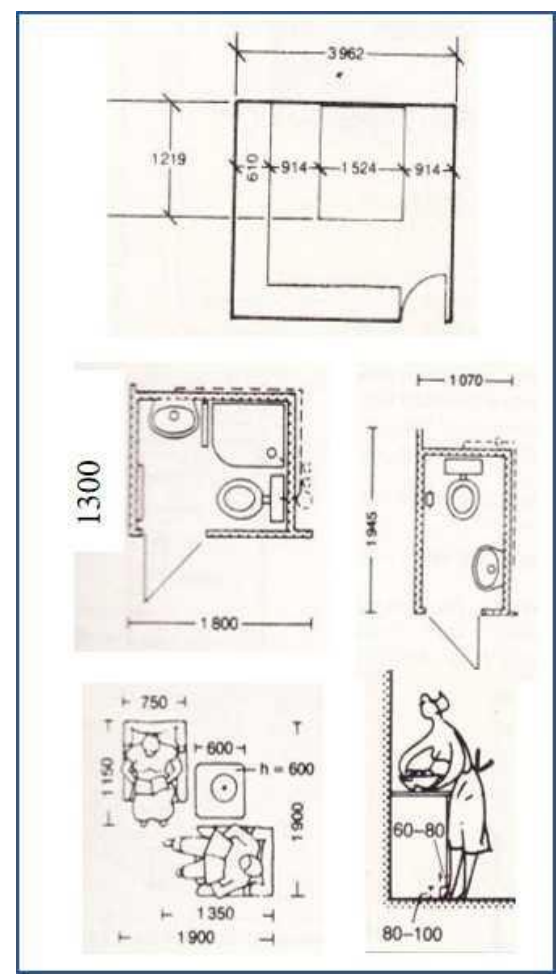

Gambar 1. Standar Besaran Ruang Sumber: Neufert (2009)

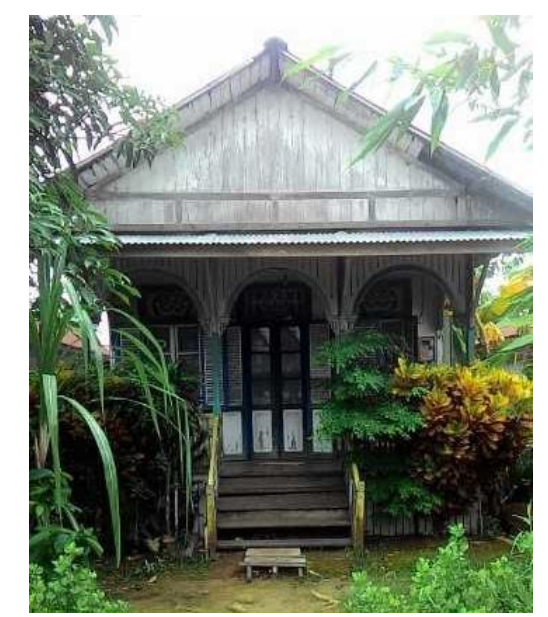

Gambar 2. Rumah kutai Model Gudang Sumber: Dokumentasi pribadi (2018)

Model jendela sebagaimana rumah Kutai pada umumnya adalah jendela kupu-kupu yang sangat cocok untuk iklim Kalimantan Timur yang dilewati garis khatulistiwa. Pada bagian atas dinding terdapat ventilasi udara. Warna yang digunakan cenderung kalem memberikan kesan sejuk pada hunian. Selain itu saat ini juga banyak digunakan jendela ungkit dengan berbagai model. 
Kebutuhan ruang untuk kamar tidur mengacu pada ukuran tempat tidur yang digunakan. Pada standar data arsitek (Neufert, 2003) dapat dilihat ukuran kasur adalah sekitar lebar 1,5 meter dengan panjang sekitar 1,2 meter. Penempatan kasur akan menentukan sisi ruang gerak pada kamar. Untuk ruangan yang tidak terlalu lebar lebih baik kasur ditempatkan pada pojok ruang. Dari modul 3 x 3 meter masih tersisa ruang sekitar 1,8 x 1,5 meter untuk sirkulasi dan perabotan lainnya. Selanjutnya untuk kamar mandi/wc pada gambar 1 lebar minimal dengan bak mandi adalah 1,3 meter. Penggunaan bak mandi masih dianggap sangat umum dan perlu dalam rumah tangga di Indonesia. Sedangkan posisi wastafel merupakan tambahan saja. Selanjutnya untuk dapur diambil lebar meja dapur dengan ukuran 60 sampai $80 \mathrm{~cm}$. bagian bawah dan atasnya dapat sekaligus sebagai wadah penyimpanan. Adapun untuk ruang tamu pada gambar diperlukan ruang sekitar 1,9 x 1,9 meter. Kebutuhan ruang yang ada di sini adalah kebutuhan minimal yang harus terpenuhi dalam perancangan sebuah rumah. Jika tidak maka rumah akan terasa sesak dan orang tidak akan nyaman untuk beraktivitas di dalamnya.

Modul ruang yang dapat digunakan adalah variasi antara 3 dan 4 meter. Modul ini dipilih dengan memudahkan pengerjaan sesuai dengan ukuran kayu yang ada di lapangan. Modul ini juga memudahkan pembagian ruang sesuai fungsinya dengan tetap mampu menampung perabotan pada ukuran standar sesuai Data Arsitek. Modul dasar tadi dapat dikembangkan menjadi modul gabungan untuk mendapatkan ruang yang besar seperti ruang keluarga. Selanjutnya modul juga dapat dikurangi dengan cara dibagi jika diperlukan ruang yang lebih kecil. Hal ini dilakukan untuk memberi ruang pada kamar mandi/wc. Sisa ruang yang tercipta dapat digunakan sebagai dapur maupun ruang lainnya.

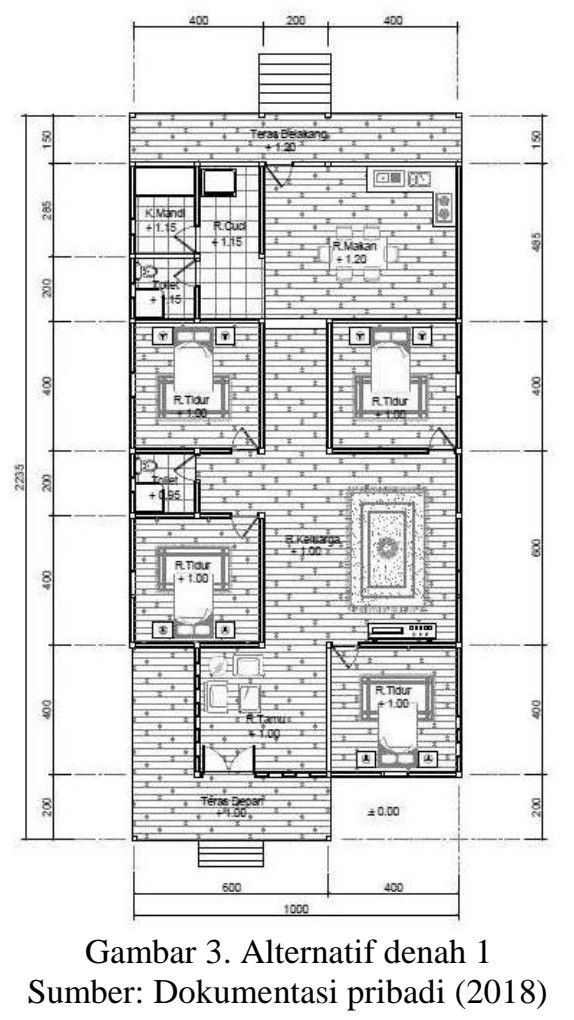

Pada alternatif denah 1 (gambar 3) nampak adanya variasi ruang. Modul yang digunakan berukuran $4 \times 4$ meter, menampung empat kamar tidur tipikal, ruang tamu, ruang keluarga, dapur yang menyatu dengan ruang makan serta area kamar mandi/toilet dan ruang cuci. Meski pun kecil pada bagian belakang dan depan bangunan terdapat teras. Bentuk ruang yang cenderung menerus memberikan privasi yang lebih banyak pada pemilik. Sirkulasi yang 
tercipta juga jauh dari monoton. Perletakan ruang memanjang sehingga pencahayaan dan penghawaan alami dalam bangunan dapat berlangsung dengan baik.

Selanjutnya pada alternatif denah 2 menggunakan variasi modul $3 \times 3$ meter dan $4 \times 4$ meter. berbeda dengan denah sebelumnya, pada rancangan ini terdapat kamar tidur utama dengan kamar mandi/toilet tersendiri. Hal ini tentu menjadi sebuah kelebihan sehingga tidak menjadi tipikal dengan kamar tidur lainnya. Ruang tamu, ruang keluarga, dan ruang makan berada dalam garis sejajar yang dipisahkan dengan dinding atau partisi. Pada bagian depan dan belakang terdapat teras dengan tangga menuju keluar. Perletakan ruang terkesan dinamis dengan banyak bukaan pada sisi dindingnya. Pada bagian depan juga diberikan ruang untuk area parkir.

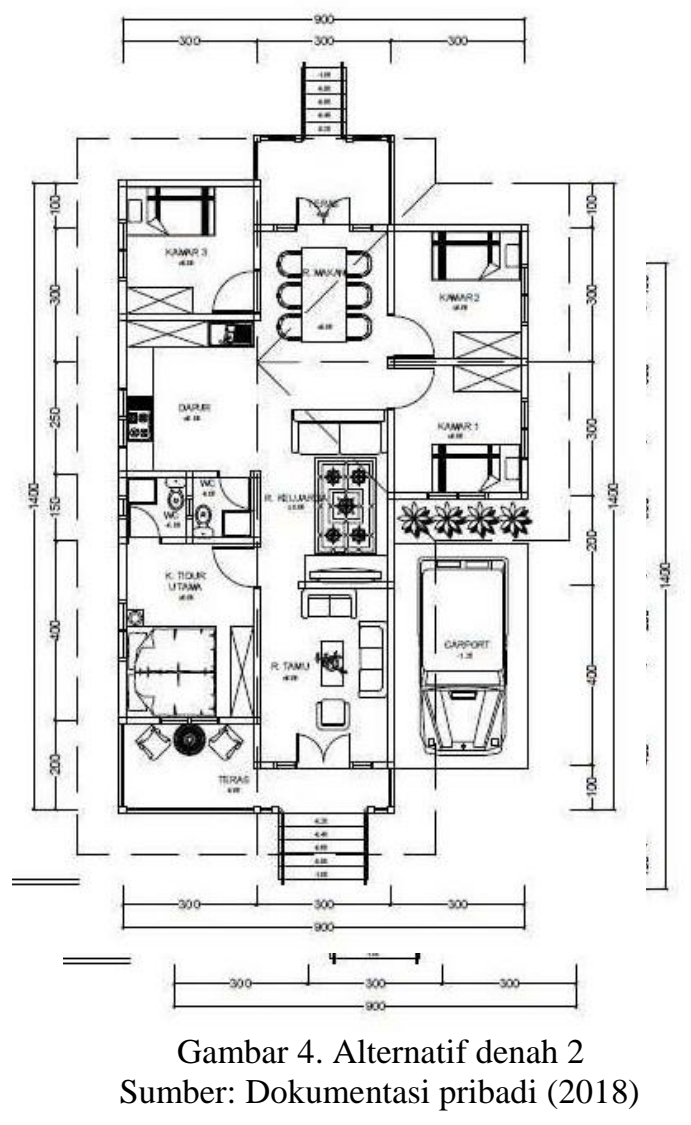

Dari kedua alternatif dapat dilihat bahwa model denah kedua (gambar 4) lebih variatif dari sisi peruangan. Selain itu adanya ruang tengah yang melorong sampai pada bagian belakang bangunan sangat membantu jika diperlukan dalam perhelatan atau acara keluarga. Keberadaan kamar mandi/wc pada ruang tidur utama juga memberikan privasi lebih pada pengguna. Selanjutnya model ini dibuat desain arsitekturalnya.

Pada tampak model rumah terpilih (gambar 5) dapat dilihat keseimbangan pada bagian depan khususnya area teras. Pada model ini desain menggunakan sumbu imajiner pada bagian tengah bangunan sebagai patokan pencerminan yang menghasilkan fasade bangunan yang sama baik pada bagian kiri maupun kanan muka bangunan. Namun demikian, keseimbangan formal di sini mengacu sampai pada bentukan atap depan, ragam hias dan lengkungannya. Pada posisi pintu dan jendela dibuat tidak simetris sesuai dengan posisi ruang yang ada dibelakangnya yakni ruang tamu dan kamar. Demikian pula pada tampak kiri dan kanan bangunan juga berbeda karena posisi ruang-ruang pada sisi tersebut. 


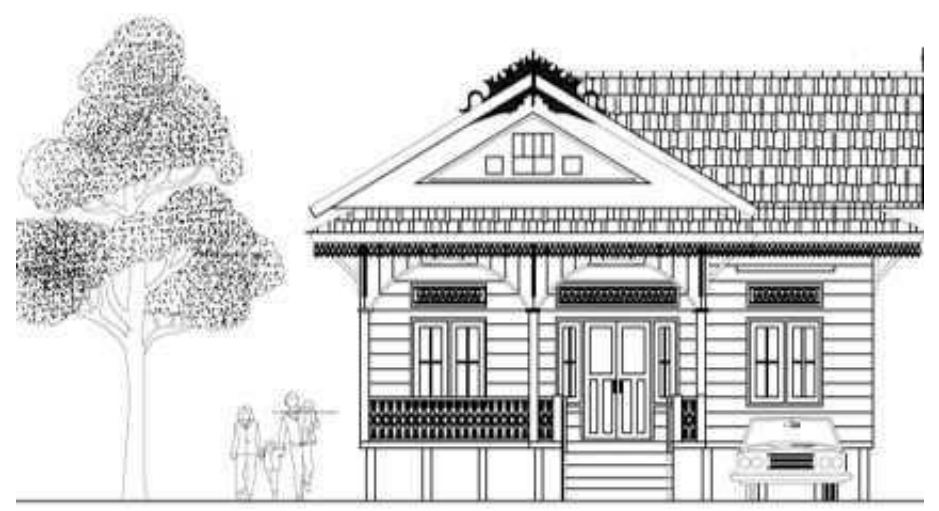

Gambar 5. Tampak depan

Sumber: Dokumentasi pribadi (2018)

Selain pada bentuk bangunan secara keseluruhan, prinsip simetris juga digunakan pada bentukan pintu dan jendela dengan model jendela ungkit dan kusen gendong pada pintu. Jika ingin menampilkan kesan yang lebih kuno dapat digunakan kaca es (kaca kembang). Banyaknya bukaan membuat sistem penghawaan udara secara silang (cross ventilation) dapat berlangsung dengan optimal. Desain ini juga dibuat sebagai jawaban bagi desain-desain modern yang justru seringkali tidak mengakomodir iklim tropis dengan baik sehingga pada akhirnya banyak menggunakan pencahayaan dan penghawaan buat yang sangat boros energi. Penggunaan desain yang mengacu pada karakter rumah Kutai ini juga bertujuan untuk membangkitkan nostalgia. Hal ini amat penting karena semakin berkurangnya jumlah rumahrumah lama membuat masyarakat terutama generasi muda kurang bahkan tidak mengenali arsitektur tradisional daerahnya.

Pada tampak depan dan samping nampak jelas penggunaan kolong/panggung pada bangunan. Panggung merupakan konstruksi khas rumah Kutai sebagai respon terhadap karakter alam Kalimantan Timur yang banyak memiliki rawa. Desain panggung dibiarkan terbuka agar dapat melewatkan air sehingga mengurangi resiko banjir. Selanjutnya estetika dilihat dari penggunaan ragam hias pada bangunan. Desain dibuat untuk dapat dijangkau oleh banyak kalangan sehingga pada desain terpilih tidak terlalu banyak menggunakan ragam hias. Ragam hias diaplikasikan pada angin-angin (ventilasi) baik pada bagian atas pintu maupun jendela serta ventilasi pada area KM/WC. Selanjutnya juga digunakan pada pagar serta lis lengkungan (arch) pada teras depan serta lisplang. Meski pun demikian, kesederhanaan ini tidak mengurangi estetika pada bangunan karena dari sisi komposisi bangunan baik bentukan atap dan maupun bagian dinding (termasuk pintu dan jendela) sudah indah.

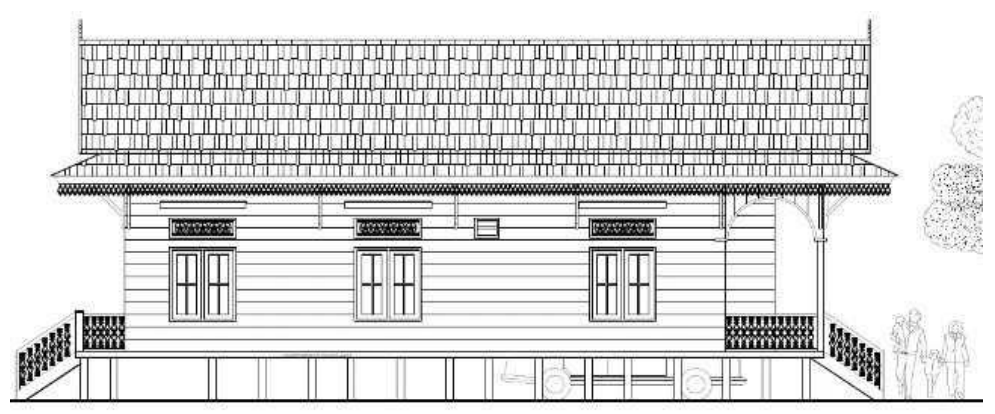

Gambar 6. Tampak Samping Kiri Sumber: Dokumentasi pribadi (2018) 


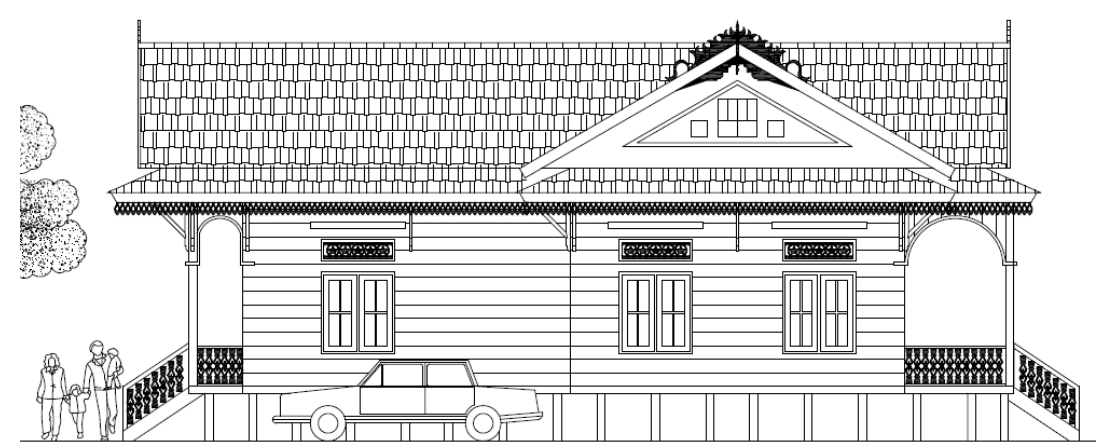

Gambar 7. Tampak Samping Kanan

Sumber: Dokumentasi pribadi (2018)

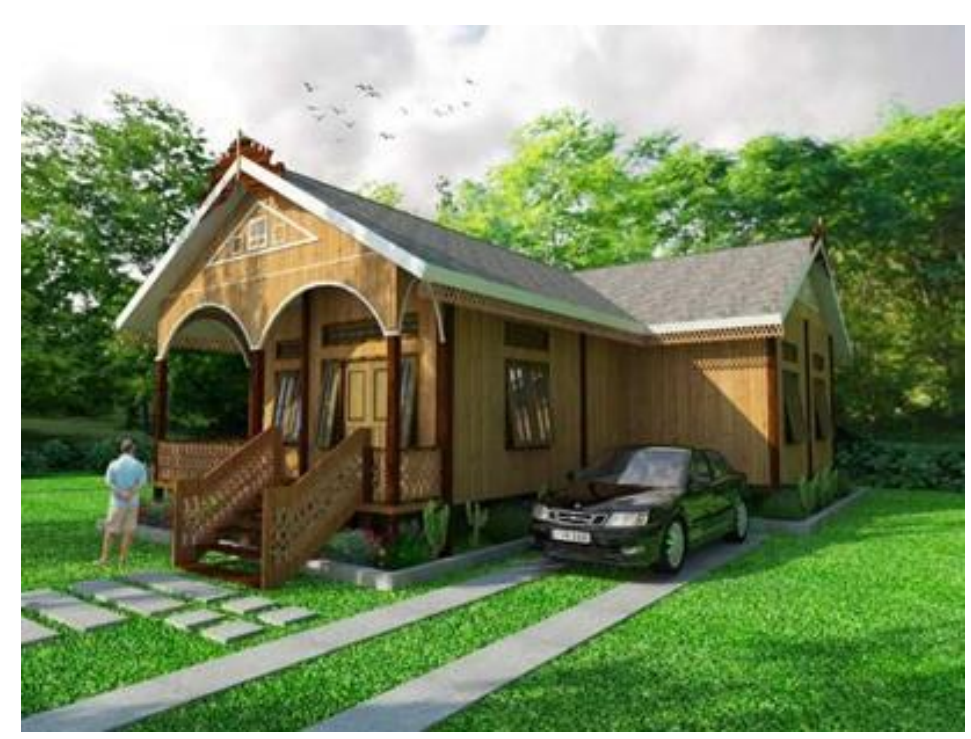

Gambar 8. Perspektif eksterior Sumber: Dokumentasi pribadi (2018)

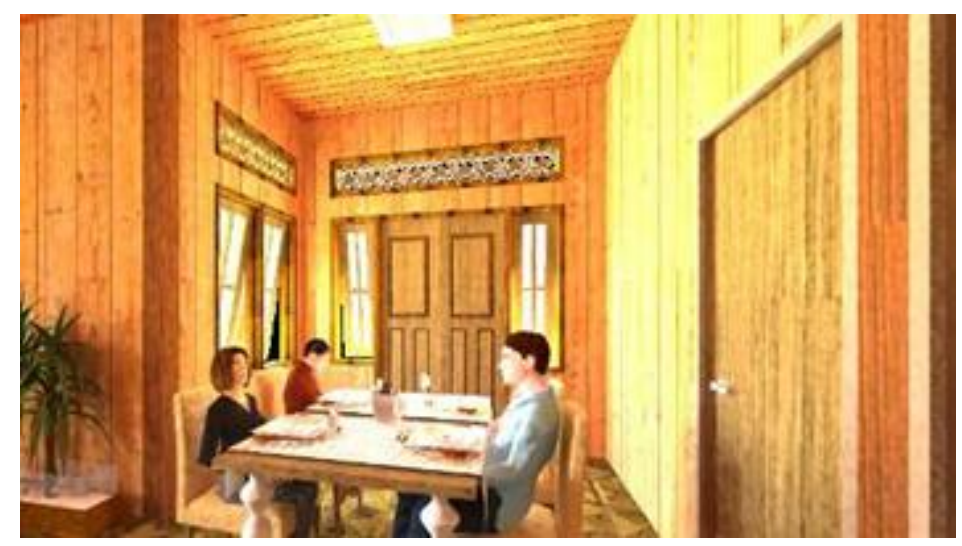

Gambar 9. Perspektif interior

Sumber: Dokumentasi pribadi (2018)

Selain pengembangan denah, tampak dan interior bangunan, pengembangan dapat juga dilakukan pada desain komponen-komponennya. Saat ini desain rumah-rumah tradisional sudah banyak diarahkan pada sistem bongkar pasang atau knock down. Contoh yang sangat populer dalam hal ini adalah rumah Tomohon dari Sulawesi Utara. Keuntungan jika 
konstruksi dibuat secara knock down adalah dapat dipindah-pindah berbeda dengan konstruksi permanen. Gambar berikut merupakan contoh detail komponen bangunan yang dapat digunakan jika dikembangkan secara knock down. Pada gambar 12 nampak contoh modul dinding. Dengan ukuran satu komponen penuh sekitar 80 × 2 meter dan 80 x 1 meter. Modul fleksibel menyesuaikan rangka dinding termasuk jika terdapat bukaan kusen maupun ventilasi udara. Lebar papan dnding yang digunakan adalah $10 \mathrm{~cm}$ jadi dalam satu modul terdapat 8 papan. Modul dirancang untuk dijepitkan pada rangka dinding.

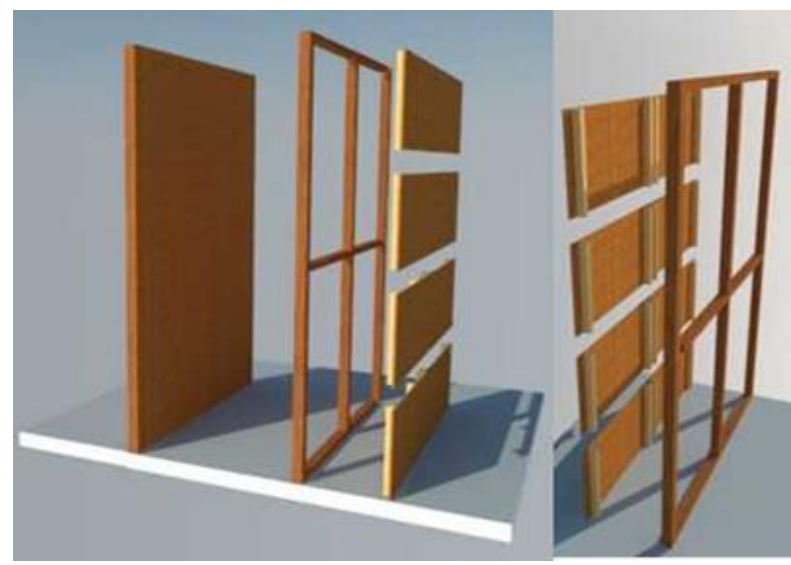

Gambar 10. Contoh Modul Dinding Sumber: Dokumentasi pribadi (2018)

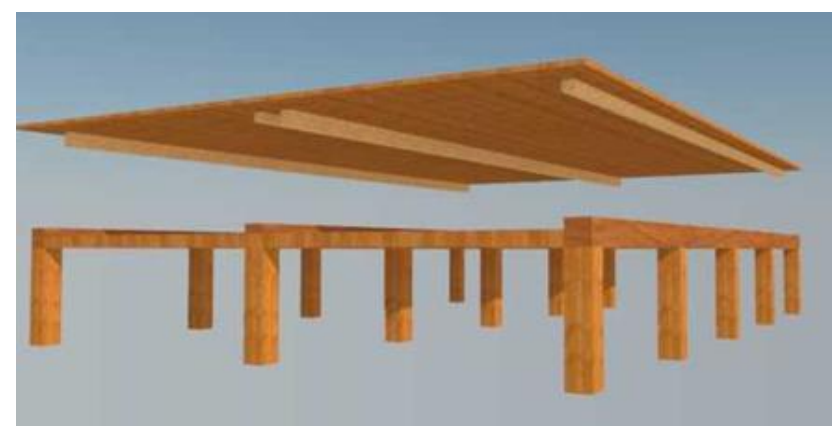

Gambar 11. Detail modul lantai Sumber: Dokumentasi pribadi (2018)

Sistem yang sama berlaku pada modul lantai namun dengan ukuran yang berbeda. Untuk lantai ukuran papan sekitar 3 sampai 4 meter lebar papan standar 18 sampai $20 \mathrm{~cm}$. Rangkaian lantai adalah 1 x 3 meter atau 1 x 4 sesuai kebutuhan.
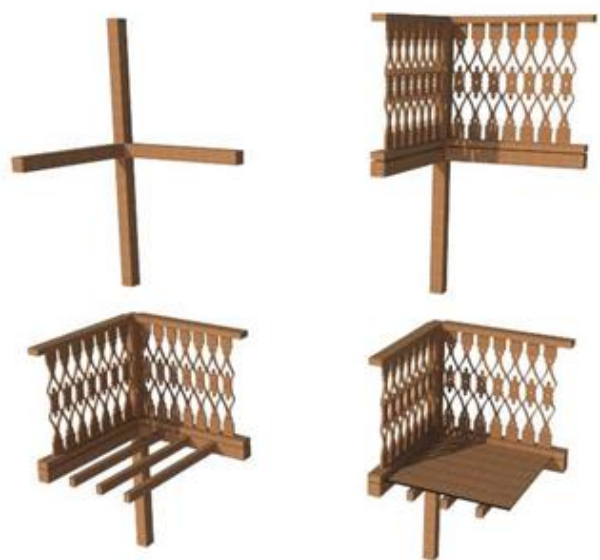

Gambar 12. Sambungan pada teras 
Sumber: Dokumentasi pribadi (2018)

Jenis kayu yang direkomendasikan digunakan adalah kayu Ulin. Kayu Ulin masuk dalam kategori kayu kelas kuat dan kelas awet nomor 1. Jenis kayu ini khas Kalimantan ini masih banyak terdapat di Kalimantan Timur. Selama ini kayu Ulin banyak dikirim ke luar daerah termasuk untuk membuat vila-vila di Bali. Berbeda dengan kayu lainnya, kayu Ulin semakin kuat jika terkena air sehingga disebut juga dengan istilah kayu besi. Karena sifatnya inilah kayu ini sangat direkomendasikan untuk konstruksi perumahan di daerah rawa seperti yang ada di Kalimantan Timur.

\section{KESIMPULAN}

Pengembangan desain rumah Kutai yang dibuat ini masih memiliki banyak kekurangan ditinjau dari berbagai aspek terutama jika ditinjau dari detail konstruksi. Aspek-aspek lainnya seperti sisi ekonomi, ketahanan gempa, pengembangan model konstruksi serta kaitannya dengan isu pembangunan berkelanjutan dapat dikembangkan pada penelitian lebih lanjut. Namun paling tidak penelitian ini membuka pemikiran tentang kemungkinan pengembangan arsitektur tradisional dalam konteks yang lebih modern. Dengan demikian, diharapkan masyarakat Kalimantan Timur khususnya kembali melihat penggunaan rumah tradisional sebagai alternatif yang dapat dipertimbangkan dalam pembangunan rumah terutama untuk daerah rawa. Alternatif model hunian dengan sistem panggung diharapkan akan dapat memberikan ruang bagi air untuk lewat sehingga air tidak akan terperangkap sebagaimana penimbunan lahan yang dilakukan pada bangunan moderen. Jika ini dilakukan maka bencana banjir tidak akan meluas sebagaimana yang terjadi di kota-kota Kalimantan Timur seperti Samarinda dan Tenggarong. Desain rumah ini juga akan memperkuat jati diri kelokalan. Selanjutnya, hasil penelitian juga dapat ditindaklanjuti dengan pengembangan desain dalam fungsi yang lebih luas tidak terpaku pada pada hunian saja.

\section{REKOMENDASI}

- Perlunya dikembangkan penelitian lebih lanjut tentang rumah Kutai dengan tipe-tipe lainnya selain tipe rumah Gudang

- Perlunya diambil langkah-langkah penting untuk mencegah arsitektur tradisional dari kepunahan.

\section{UCAPAN TERIMAKASIH}

Ucapan terima kasih disampaikan kepada Kementerian Riset, Teknologi dan Pendidikan Tinggi yang telah membiayai penelitian ini melalui Program Strategis Nasional Institusi. Terima kasih juga disampaikan kepada Unit Penelitian dan Pengabdian Masyarakat Politeknik Negeri Samarinda dan rekan-rekan yang telah mendukung penelitian ini.

\section{DAFTAR PUSTAKA}

A. Ernawati, R. Laksmitasari. (2013). Pengaruh Pergeseran Rumah Panggung Terhadap Meningkatnya Penderita ISPA di Kecamatan Tamansari Bogor, Prosiding Ikatan Peneliti Lingkungan Binaan Indonesia, 1-5.

E. Neufert. (2003). Data Arsitek. Jakarta: Penerbit Erlangga.

I.M.K Adhi Darma, A. Al Ikhsan, L. A. Hasan. (2017). Respon Rumah Tradisional Suku Bajo Terhadap Iklim Tropis, Prosiding Ikatan Peneliti Lingkungan Binaan Indonesia, 97-112.

P.A Aprimavista, , M. Wibowo, D. Wondo. (2013). Terapan Konsep Bangunan Tradisional Bali Pada Obyek Rancang Bangun Karya Popo Danes, Jurnal Intra 1(1), 1-8. 
S. Beddu. (2015). Arsitektur Rumah Berpanggung yang Sustainable di Lahan Berair, Prosiding Ikatan Peneliti Lingkungan Binaan Indonesia, 11-15.

Pemerintah Provinsi Kalimantan Timur. (1996). Puncak-puncak Kebudayaan Lama dan Asli Kalimantan Timur. Samarinda.

W. Mononimbar. (2014). Penanganan Pemukiman Rawan Banjir di Bantaran Sungai; Studi Kasus Pemukiman Kuala Jengki di Manado, Jurnal Engineering 4(1), 26-31.

Z. Hidayati, C. Oktavia. (2013). Studi Adaptasi Rumah Vernakular Kutai Terhadap Lingkungan Rawan Banjir di Tenggarong, Jurnal Dimensi 4(2), 89-98. 